\title{
O homem: possessão sexual, vampirismo e pecado original no romance de Aluísio de Azevedo
}

\author{
Isabel Guimarães Rodrigues Freire \\ Professora Substituta e Mestranda - UFC
}

\begin{abstract}
Resumo:
Com o presente artigo pretendemos demonstrar os resíduos da mentalidade medieval no romance $O$ homem, de Aluísio Azevedo, abordando os aspectos presentes na obra que remetam a possessão sexual, vampirismo e pecado original. Além do romance em questão, utilizamos estudos teóricos elaborados por Roberto Pontes sobre residualidade e estudos referentes à Idade Média.
\end{abstract}

Palavras-chave: Pecado; medievalismo; residualidade

Em 1887, o escritor maranhense Aluísio Azevedo publica no Rio de Janeiro o romance $O$ homem. Considerado o romance azevediano que mais ressalta aspectos do Naturalismo, esse livro tem sido posto em segundo plano quando se trata de avaliar a qualidade literária do autor. Devido ao fato de ressaltar expedientes cientificistas, através do determinismo biológico, e colocar a satisfação dos apetites sexuais acima da capacidade do indivíduo de discernir, o referido romance não recebeu a merecida valoração; poucos críticos realmente se debruçam sobre a obra a fim de lançar um juízo de valor favorável, ao contrário do que ocorre à trilogia $O$ cortiço (1890), Casa de Pensão (1884) e $O$ mulato (1881). Tendo recebido uma direta influência de Thérèse Raquin (1867), de Émile Zola, Aluísio Azevedo aborda em O homem a questão da histeria, da tirania do organismo sobre a vontade do homem (no caso em questão, representado por uma protagonista feminina), e a repressão às manifestações sexuais da mulher.

O enredo gira em torno de Madalena, filha do Conselheiro Pinto Marques, a qual nutre uma profunda afeição por Fernando, afilhado de seu pai. Contudo, tal afeição não é vista com bons olhos pelo conselheiro, que, para evitar a consumação do relacionamento de ambos, revela para Fernando um segredo arrebatador: ele e sua filha são, na verdade, irmãos, sendo Fernando fruto de um relacionamento extraconjugal do conselheiro. A revelação, além de causar profundo pesar no espírito de Fernando, provoca o distanciamento do rapaz e a consequente decisão de partir rumo à Europa, onde pretende morar. Madalena percebe o distanciamento do meio-irmão e sua frieza em relação a ela, porém atribui esse comportamento às preocupações com a formatura; qual não é sua surpresa quando o jovem se forma e anuncia sua viagem à Europa, sendo essa, sem retorno. A partir de então, Madalena sofre uma profunda decepção da qual 
jamais conseguirá se recuperar, mesmo que em alguns momentos a jovem mostre ter superado a frustração sofrida e até uma indiferença com relação à partida do amado.

Observando o início do enredo, acima descrito, o autor já revela sua intencionalidade cientificista ao tomar como ponto de partida para a narrativa um enlace amoroso entre dois irmãos. O tema do incesto, aliás, é recorrente na literatura naturalista, haja vista o romance Os Maias (1888), de Eça de Queirós. O único impedimento para a concretização do amor incestuoso são, de fato, as regras sociais, pois que não existe nenhum impedimento biológico no que diz respeito aos desejos e à atração sexual, podendo esta haver entre irmãos consanguíneos.

Observando o desespero em que sua filha se encontrava, o conselheiro não viu outra saída a não ser contar a verdade para Madalena, a qual, sabedora de tudo, tem a sensação de alívio ao saber que o motivo de ser evitada por Fernando era o parentesco existente entre eles. Um ano se passou e eis que chega uma carta da Europa avisando acerca da morte de Fernando por problemas pulmonares. Ao saber da morte do irmão, Madalena entra num processo de definhamento, em que sua vida parece perder o sentido. Seu desinteresse pelos homens que the aparecem como pretendentes é crescente, e sua saúde, já fragilizada pelo amor frustrado, parece esvair-se a cada dia que passa.

Todavia, mais do que uma obra naturalista de tese experimental, $O$ homem encerra valores e símbolos anteriores à corrente literária referida. Podem ser detectados no romance resíduos da mentalidade medieval, que, por sua vez, contêm valores herdados de outras eras. Mais do que defender uma tese de caráter científico e determinista, Aluísio ressalta valores presentes na mentalidade do século 19, que têm origem em tempos mais remotos; esses valores aparecem no romance através de fenômenos os quais pretendemos analisar sob a perspectiva da teoria da residualidade, ${ }^{1}$ elaborada por Roberto Pontes; tais fenômenos seriam: possessão sexual, vampirismo e pecado original.

A teoria da residualidade consiste em observar resquícios de uma mentalidade em outra mentalidade, resquícios esses envolvendo aspectos culturais e literários recorrentes em época distintas e que denunciam uma constância residual de determinados fenômenos. Ou seja, um aspecto literário e cultural presente na época atual pode ter sua origem em outro momento histórico, denunciando sua permanência enquanto atitude mental inconsciente. Contudo, o termo resíduo, referindo-se a essas atitudes mentais, antes de ser utilizado por Roberto Pontes ${ }^{2}$ para caracterizar a teoria da residualidade, já havia sido referido por Raymond Williams, pensador marxista de origem galesa, quando este estabelece a diferença entre "resíduo" e "arcaico", cuja diferença básica seria o fato deste possuir uma natureza estagnada, enquanto aquele estaria em constante processo de transformação, o que nos leva a um outro conceito desmembrado da teoria da residualidade, o de cristalização. O termo cristalização, a partir desta teoria, passou a ser enquadrado nos estudos literários, pois que, até então, era um termo próprio dos estudos referentes à mineralogia, recebendo nessa perspectiva cultural e literária uma nova atribuição. A cristalização, portanto, está associada à ideia de remanescentes que permanecem, porém, atualizados, modificados; e assim como um cristal, que pode ser modificado e utilizado com diferentes finalidades, o resíduo sofre transformações e se aclimata ao local onde se faz presente e se atualiza agregando os valores da época em questão.

\footnotetext{
1 A teoria da residualidade serve de base aos estudos do grupo de pesquisa Estudos de Residualidade Cultural e Literária, certificado pela UFC e cadastrado junto ao CNPq.

2 PONTES. Poesia insubmissa afrobrasilusa.
} 
Vê-se que o termo "mentalidade" aparece com muita frequência quando o assunto vem a ser de residualidade, visto não ser possível conceber o princípio residual sem o conceito de mentalidade. As concepções referentes às mentalidades ganharam força com os estudos dos pensadores da Escola dos Annales, da qual Lucien Febvre e Marc Bloch foram os fundadores. Além dos supracitados, Jacques Le Goff e Georges Duby participaram do movimento, o qual viria a ser fundamental para o estabelecimento da Nouvelle Histoire francesa. A Escola dos Annales propõe uma nova perspectiva de ver a história, levando em consideração não só os acontecimentos no nível da macroestrutura, ou seja, as revoluções, as batalhas e conflitos de grande porte, mas a história implicada nas microestruturas: nos hábitos, nos costumes, na religião, nas crenças populares, nessas estruturas nem sempre contempladas pelos manuais de História e que compõem as mentalidades, como podemos observar nas palavras do próprio Jacques Le Goff no livro Em busca da Idade Média:

Sentia muito claramente nossa entrada numa outra era. Adivinhava que essas mudanças materiais, cotidianas, eram um dos componentes fundamentais da História. Que a História, ainda uma vez, não se limitava às batalhas, aos reis, aos governos. Uma certa maneira de ser e de pensar tornava-se ultrapassada. Mais tarde, chamaria esse movimento de mudança de mentalidade - mudança que acompanharia as trocas materiais. ${ }^{3}$

Destarte, levando em consideração o conceito de mentalidade desenvolvido pelos pensadores da Escola dos Annales e o conceito de resíduo, de Raymond Williams, tem-se duas das bases constituintes da teoria da residualidade, a qual nos servirá de fundamentação teórica a fim de relacionar o romance aqui abordado e a mentalidade medieval, pois, como Jean-Maurice de Montremy, no prólogo de Em busca da Idade Média, afirma:

É exatamente o nosso problema: somos freqüentemente medievais quando nos vangloriamos de sermos modernos; e freqüentemente não passamos de "apreciadores da Idade Média" quando acreditamos nos enraizar no tempo das catedrais, dos cavaleiros, dos lavradores e dos comerciantes. Os códigos e os valores desse longínquo passado próximo são bem mais estranhos a nós do que habitualmente pensamos. Mas lhe devemos bem mais do que queremos admitir. ${ }^{4}$

O primeiro assunto a ser abordado neste trabalho será a possessão sexual. Tem-se por possessão sexual a ação de seres malignos, também conhecidos como demônios do sexo, sobre as pessoas, tanto do sexo masculino como do feminino. Tais demônios na Idade Média receberam as denominações de "íncubo", quando assumiam forma de homem para seduzir mulheres, e "súcubo", ao assumirem forma de mulher a fim de apossar-se de homens. Na Idade Média, o íncubo (do verbo latino incubare, que significa "deitar-se sobre", referindo-se à posição masculina sobre a mulher durante o ato sexual), e o súcubo (do verbo sucubare, ou "deitar-se sob", o que seria uma referência à posição feminina abaixo do homem na relação carnal) serviram para justificar as frequentes recaídas sexuais dos indivíduos em meio a uma sociedade opressora e que aprisionava as realizações eróticas sob o estigma do pecado judaico-cristão. Os principais alvos dos "ataques" noturnos dos possessores eram aquelas pessoas em torno das quais havia algum tipo de impedimento à realização sexual, como padres, freiras, mulheres casadas e camponeses. Desta forma, a fim de evitar a assunção do ato sexual realizado efetivamente com alguém do seu convívio, o possuído atribuía as consequências desse ato (polução noturna dos homens, gravidez indesejada em freiras e resquícios de

\footnotetext{
${ }^{3}$ LE GOFF. Em busca da Idade Média, p. 27.

${ }^{4}$ MONTREMY. Prefácio, p. 12.
} 
secreções em mulheres casadas quando estas não praticavam sexo com seus maridos) à ação maléfica de seres demoníacos durante o sono.

O pavor a esses seres das trevas, que perturbavam o sono das pessoas com o intuito de possuí-las sexualmente, foi muito intensificado pela ação da Igreja Católica, que, objetivando infligir medo e receio com relação a eventos naturais da sexualidade humana, mascarou tais ocorrências com uma motivação diabólica. A alegativa da Igreja era a de que o homem de Deus deveria purificar-se e distanciar-se dos prazeres carnais a fim de chegar a Ele; caso o homem insistisse em ceder às tentações, estaria compactuando com as entidades ligadas ao maligno. Muitas vezes, porém, os íncubos serviram para camuflar a exploração sexual masculina em relação às mulheres, que após terem sua alcova invadida por um homem comum acreditavam terem sido possuídas por um demônio que assumiu a forma de homem. Com relação aos camponeses, estes sofriam, mais do que a nobreza, os impactos do fanatismo religioso, haja vista o fato de o número de mulheres camponesas queimadas nas fogueiras da Inquisição, acusadas de bruxaria, ser superior ao número de mulheres aristocratas. No meio campesino, a fé católica exercia maior influência na mente e nos hábitos das pessoas, pois, ao contrário da nobreza, os camponeses não tinham prestígio e nem posses que lhes valessem, caso fossem acusados pelos tribunais inquisitoriais.

Vale ressaltar, contudo, que a ideia de entidades ligadas ao sexo, que travam relações sexuais com humanos, tem origem bastante anterior à Idade Média, e faz parte do imaginário de várias culturas, não só da cultura europeia, mas até a do Oriente, pois há registros bastante contundentes, embora raros, que atestam a crença de alguns povos orientais na existência de seres possessores. A amplitude desta temática não só possui uma dimensão espacial, estando presente tanto no imaginário do Ocidente como na do Oriente, mas também possui uma dimensão temporal, pois muito antes da Idade Média, já quando existiam as lendas pagãs celtas, a ideia do íncubo e do súcubo está presente, como podemos observar na lenda do rei Arthur, cujo mestre, o mago Merlim, seria filho de uma mulher terrena com um demônio (desse parentesco, o mago teria herdado sua essência mística). É comum em todas as culturas que possuem a representação dos demônios do sexo, possuírem estes uma beleza fora do comum e irresistível. Na Idade Média, a imagem dos íncubos e súcubos era asquerosa, grotesca e bestial, porém, quando do momento da possessão, eles se revestiam de uma beleza sem igual; consumado o ato, reassumiam a forma original repugnante.

No romance $O$ homem, a protagonista Madalena, por conta do agravamento da sua debilidade física e mental, leva seu pai a mudar de cidade, vindo ambos a habitar uma chácara na Barra da Tijuca. Esta chácara situa-se defronte a uma pedreira, o que torna propício o encontro de Madalena com o personagem Luís, trabalhador da pedreira. Madalena passa a ter sonhos eróticos com o rapaz. Ao travar o primeiro contato com ele, quando se acidenta e é resgatada pelo moço, a jovem sente repugnância ao sentir tocar sua pele o corpo suado e moreno do trabalhador; muito desta repugnância dá-se pelos traços rústicos do rapaz, mas também por conta de um profundo sentimento de recato e pudicícia vindo da moça, educada conforme os costumes conservadores da época. Apesar desta repugnância, no seu íntimo, a masculinidade do homem sensibiliza seus sentidos de "fêmea". A passagem a seguir ilustra o momento seguinte ao primeiro contato travado entre Madalena e Luís, e mostra o sentimento de repulsa daquela com relação a este:

Mal se pilhou no quarto, Magdá foi estraçalhando as roupas, como se as trouxera incendiadas; mas sentia também nos seus cabelos, no seu rosto, em toda ela, o mesmo cheiro de animal suado, o mesmo enjoativo bodum de 
carne crua. Parecia-Ihe mais - que a sua própria transpiração já tresandava àquele mesmo fartum do moço da pedreira.

- Diabo! Diabo! Diabo!

E os movimentos que fazia para sacar a camisa eram tão violentos, que ela parecia querer arrancar até a própria pele do corpo. ${ }^{5}$

Ao deitar-se, a jovem sonha com o trabalhador da pedreira e, no sonho, o rude sujeito assume a forma de um belíssimo homem, encantador, muito diferente do homem simples e rústico da realidade. Leiamos o trecho:

Sonhou com ele a noite inteira; mas que sonhos! E o melhor é que então o pobre diabo já lhe aparecia não por um prisma repugnante; ao contrário, imaginando-se ao lado daquele corpo robusto, Magdá sentia todo o seu organismo rejubilar de satisfação, ainda melhor do que quando se aninhava no colo de Justina. Perto dele gozava, em sonho, um bem-estar de calmo conforto, como o dos tísicos junto aos bois, na morna atmosfera dos currais. ${ }^{6}$

Podemos, então, estabelecer uma comparação entre o íncubo medieval, demônio horrendo que durante o sono possui a vítima do sexo feminino, metamorfoseado em belíssima imagem com o personagem Luís, o qual exerce terror sobre Madalena enquanto esta se encontra em estado de vigília e, ao mesmo tempo, exerce fascínio sobre ela quando está adormecida. E, além disso, durante o sonho, Madalena rejubila-se na presença do jovem trabalhador e desfruta o estado onírico dos prazeres que o jovem Ihe proporciona; todavia, quando acorda, é tomada por profundo arrependimento e pesar, que tenta aplacar com fervorosas orações:

E o que ela não se animou de confiar ao médico, disse em confidência de alcova ao seu crucifixo, pedindo-Ihe entre lágrimas, pelo amor da Virgem Mãe Santíssima, que a protegesse; que a livrasse daqueles pensamentos impuros, que the mandasse dos céus todas as noites um dos seus anjos para the velar o sono e impedir que a sua pobre alma, enquanto ela dormia, fosse vagabundear por ali, como a alma de qualquer perdida. ${ }^{7}$

Interessa também ressaltar a ideia, muito presente na mentalidade medieval, de um mal que consome, que se alimenta do ser humano e está presente como um parasita. Isto nos remete ao pensamento de santo Anselmo, filósofo e teólogo medieval do século 11, de origem normanda:

Existe um mal, um mal acima de todos os males, que tenho consciência de que está sempre comigo, que dolorosa e penosamente dilacera e aflige minha alma. Esteve comigo desde o berço, cresceu comigo na infância, na adolescência, na minha juventude e sempre permaneceu comigo, e não me abandona mesmo agora que meus membros estão fraquejando por causa da minha velhice. Este mal é o desejo sexual, o deleite carnal, a tempestade de luxúria que esmagou e demoliu minha alma infeliz, sugando dela toda a sua força e deixando-a fraca e vazia. ${ }^{8}$

Madalena sente o mesmo, uma presença nefasta e perseguidora, que a consome e não a quer deixar em paz:

E tomou as mãos do Conselheiro, fazendo-o chegar-se para bem junto dela. $\mathrm{E}$, depois de contemplá-lo em silêncio com um meio sorriso, abraçou-o, demoradamente, como se procurasse ficar convencida por uma vez de que aquelas tolices do sonho não tinha o menor fundamento, e que seu pai, o seu extremoso pai, a quem tanto queria do fundo do coração, ainda ali estava ao

\footnotetext{
${ }^{5}$ AZEVEDO. O homem, p. 72.

${ }^{6}$ AZEVEDO. O homem, p. 73.

7 AZEVEDO. O homem, p. 73.

${ }^{8}$ Santo Anselmo (1033-1109), arcebispo da Cantuária e um dos doutores da Igreja Católica.
} 
seu lado, para amá-la como sempre e protegê-la contra o maldito intruso que habitava dentro dela e que a consumia para alimentar-se. ${ }^{9}$

Outro fenômeno a ser observado como presença residual no romance seriam as manifestações vampíricas que giram em torno da personagem Madalena. Este fato nos causa surpresa, pois a temática vampiresca no imaginário literário esteve sempre associada à literatura científica do século 18 e à romântica do século 19, daí que a retomada desta temática num romance naturalista e experimental se nos afigura surpreendente.

O vampirismo tem origens bastante remotas. Desde a Antiguidade, podem ser encontradas narrativas e relatos relacionados a criaturas mortas-vivas que saem de seus túmulos à caça de sangue para se manterem existindo jovens e belas, ou mesmo para estabelecer e manter seu pacto com o maligno. Nas mitologias assíria e babilônica, três mil anos antes de Cristo, encontramos os "labartu", criaturas que se alimentavam de sangue, tanto de animais quanto de humanos, preferencialmente o de crianças. Vale ressaltar que as manifestações vampirescas sempre estiveram associadas aos pecados cometidos pelos membros de uma comunidade. Geralmente, as irrupções vampirescas ocorriam quando uma quebra nos ritos religiosos se realizava, quando um ritual fúnebre não era bem-sucedido, ou quando uma das etapas deste ritual não era concretizada; o morto, então, ficaria preso à existência corpórea, o que também ocorreria quando uma criança falecesse sem ter sido batizada. $O$ ocultismo também acarretaria tais manifestações; rituais pagãos e bruxaria seriam uns dos principais motivos; em seguida, veremos a relação da bruxaria com o vampirismo e de que forma as bruxas sempre estiveram associadas aos mortos-vivos. Na Romênia, a causa para a ocorrência de uma aparição vampiresca seria o nascimento de filhos ilegítimos, frutos de relacionamentos extraconjugais, crença particularmente interessante na análise do romance $O$ homem, visto ser Fernando filho ilegítimo. Além dessas causas já referidas, outra visivelmente oportuna para nossa análise, dada a relação com o romance aqui estudado, era a ocorrência de incesto, pois, muitas vezes, o vampiro seria o filho fruto de uma relação incestuosa. $O$ incesto, principalmente na Idade Média, teria como consequência a manifestação de forças demoníacas na comunidade e, como punição, esta seria vítima dos ataques de criaturas malignas, bebedoras de sangue. Vejamos, portanto, a relação estreita existente entre as irrupções vampirescas e os códigos morais estabelecidos pelas sociedades de diversas épocas e localidades, sabendo que a quebra desses códigos e a prática de atos considerados pecaminosos estão estreitamente vinculadas ao surgimento de forças malignas, como podemos deduzir da passagem do livro Lendas de sangue, de Flavia Idriceanu e Waine Bartlett:

Essas criaturas de além-túmulo, sedentas de sangue, assombraram todos os cantos da Europa. Eram até mais aterrorizantes por serem a representação do nascimento do mal no seio da comunidade, uma terrível ruptura da vida diária normal. Um vampiro é, geralmente, o resultado de uma transformação e, por meio desta, um inocente se tornava um corrupto; assim, um mero acidente ou a quebra de um tabu moral ou social desencadeava os poderes do Inferno. O processo de transformação em tal criatura divergia de uma região a outra, refletindo as características culturais específicas de cada área. ${ }^{10}$

Observemos de que forma surgem, no romance $O$ homem, manifestações que aproximam a protagonista Madalena do vampirismo. Além de ter-se apaixonado por um rapaz, filho bastardo de seu pai, condizendo com a configuração de um amor incestuoso,

\footnotetext{
${ }^{9}$ AZEVEDO. O homem, p. 79.

${ }^{10}$ IDRICEANU; BARTLETT. Lendas de sangue. O vampiro na história e no mito, p. 15.
} 
Magdá, como também era conhecida, passa a enfraquecer a olhos vistos e a perder o viço da mocidade, ao passo que sua beleza estonteante é profundamente comprometida, a ponto de sua fisionomia adquirir um aspecto cadavérico e mais aproximado da morte. Quando dos seus sonhos com o cavouqueiro, Magdá revela intensamente seu desejo de sangue, como se sua existência dependesse da ingestão de sangue jovem e forte para se manter viva. Observe-se a passagem a seguir, extraída de um dos sonhos de Madalena, ressaltando que em seus sonhos a moça vivia uma espécie de realidade paralela, na qual se manifestavam seus ímpetos vampirescos:

- Não, não! gemeu a moça, segurando-o com ambas as mãos, - Não te afastes de mim! Não é de água que eu preciso, é de um pouco de vida! Sinto fugirem-me as forças! Eu preciso de sangue.

E fazia-se cor de cera, e fechava os olhos, e entreabria os lábios, como um orfãozinho abandonado que morre à míngua do leite materno.

Cortava o coração.

- Magdá! Meu amor! Minha vida! Exclamou Luís, tomando-a nos braços. Não desfaleças! Não fiques assim! Desperta!

Ela soergueu as pálpebras, e murmurou baixinho, quase imperceptivelmente:

- Sangue! Sangue! Sangue, se não eu morro!...

- Ah! fez o moço com vislumbre. E sem sair donde estava, quebrou um espinho da palmeira e com ele picou uma artéria do braço. - Toma! disse, apresentando à amante a gota vermelha que havia orvalhado na brancura da sua carne. - Bebe!

Magda precipitou-se avidamente sobre ela e chupou-a com volúpia. Não se ergueu logo; continuou a sugar a veia, conchegando-se mais ao amigo, agarrando-se-lhe ao corpo, toda grudada nele, apertando os olhos, dilatando os poros, arfando, suspirando desafogadamente pelas narinas, como se matasse uma velha sede devoradora. ${ }^{11}$

Ao acordar de sua vida paralela, de seu mundo maravilhoso e paradisíaco, Madalena sente refletidos os resquícios desta existência na vida real, além do abatimento moral provocado pelo sentimento de culpa em saciar seus desejos carnais através da virilidade do Luís da sua imaginação; Madalena está constantemente sentindo gosto de sangue na boca, o que leva o leitor à ideia de que sua existência vampiresca não se restringe somente aos seus sonhos:

A criada afastou-se, e Magdá ficou a estalar a língua contra o céu da boca. Era ainda o terrível gosto de sangue que não a deixava. ${ }^{12}$

A recorrência de referências a colorações avermelhadas nos revela claramente a intencionalidade do autor em reiterar a simbologia do sangue, associada sempre à ideia de vida, saúde e juventude, como pode ser observado em uma das falas de Madalena:

- Sonhei com tudo isto que nos cerca neste nosso éden; sonhei com esta gruta, com estas árvores, com estes lagos e com esta deliciosa luz sangüínea que me aviventa. ${ }^{13}$

Isso nos conduz à necessidade de fazer uma breve explanação acerca da simbologia do sangue, a que interpretações esse fluido vital tem sido submetido ao longo dos tempos no imaginário cultural e religioso.

O sangue tem estado associado, desde tempos imemoriais, aos conceitos de vida e morte, sacrifício e glória, sendo também símbolo de força, poder e juventude. Em muitas crenças, pagãs ou judaico-cristãs, o sangue assume papel central no que diz respeito a estabelecer um pacto entre o homem e a divindade. No simbolismo cristão, o sangue

${ }^{11}$ AZEVEDO. O homem, p. 110.

12 AZEVEDO. O homem, p. 115.

${ }^{13}$ AZEVEDO. O homem, p. 106. 
ganhou força principalmente se considerarmos a passagem bíblica tão conhecida d'A Última Ceia. Nesta passagem, observamos a importância e o valor atribuídos ao sangue quando Jesus concede aos homens a oportunidade de compartilhar seu corpo e seu sangue através do pão e do vinho. Esse ritual, inclusive, já era existente em rituais pagãos nos quais se fazia uso do vinho para comungar com os deuses. No Velho Testamento, a associação do sangue ao sacrifício é ainda mais forte, e nos certificamos disso na presença da ideia de sacrifício representada pelo bode expiatório, também quando Deus pede a Abraão que mate seu filho Isaque para provar sua fé, e ainda no episódio do assassinato de Abel pelo irmão Caim:

Sob muitos aspectos, o Velho Testamento está inundado de imagens de sangue. Na história de Caim e Abel, o sangue está associado à inocência, ao pecado e ao pós-vida. O sangue derramado é a testemunha do crime, do além-morte, levando Deus a indagar: "O que fizeste? O sangue de teu irmão clama da terra". No mito do vampiro, o sangue é o vínculo demoníaco entre o morto e o mundo dos vivos, e as lendas falam que o morto-vivo grita das tumbas os nomes de suas vítimas. ${ }^{14}$

No romance em questão, o sangue simboliza fortemente a ideia de saúde, juventude e beleza, atributos dos quais a protagonista é dotada, mas que vão-se esvaindo à medida que a moça se vê mais tomada pela doença. Aos poucos sua saúde enfraquece, sua beleza se esmaece, obscurecida por extrema palidez e profundas olheiras. Diante desta realidade aterradora, de ver-se cada vez mais fragilizada e ter sua vida por um fio, Madalena sente necessidade (em sonho) de beber sangue, como já foi mostrado acima e, ao fazê-lo, a mudança operada é deslumbrante:

As suas faces eram de novo duas rosas que atraíam beijos, como o matiz das flores atrai sobre a sua corola o inseto portador do pólen; os olhos rebrilhavam-Ihe já com a sedutora expressão primitiva. Os seus lábios trêmulos recuperaram logo o perdido sorriso dos tempos passados; a garganta carneou-se, reconquistando as linhas macias, as doces flexibilidades da pele sã; as curvas do desnalgado quadril retomaram enérgicas ondulações; os seios empinaram; as coxas enrijaram; e toda ela se retesou, se refez de músculos e nervos, numa súbita revisceração deslumbradora. ${ }^{15}$

Esse episódio do romance nos lembra um caso verídico, digno de ser referido nesta análise devido à sua importância quando se trata da temática vampiresca. É o caso da condessa Elisabeth Bathory (1560-1614), a qual foi acusada e condenada de torturar e matar jovens mulheres por puro prazer sádico e a fim de aproveitar-se de seu sangue para manter a juventude. A condessa, nascida na Hungria e pertencente a uma riquíssima e influente família daquele país, era dotada de rara beleza e muitos dotes intelectuais, que a tornavam extremamente atraente, e uma personalidade marcante. Diz-se que um dia, sendo penteada por uma criada, foi machucada por um puxão nos cabelos provocado por esta; enfurecida com a moça, bateu nela até sangrar. O sangue da criada teria respingado em seu rosto e, passado um tempo, a condessa teria percebido que no local onde o sangue havia respingado, a pele estaria mais bela, jovem e sedosa como a pele das donzelas. Esse episódio sangrento teria sido uma das motivações para que Elizabeth adquirisse o hábito de não só torturar e matar jovens moças, mas também de entrar em contato com seu sangue a fim de manter eterna beleza e refrear o aparecimento da velhice, a qual já se fazia notar. Mesmo tendo sido denunciada e condenada à reclusão total em seu castelo, em cujo quarto a condessa ficaria presa e emparedada por grossa massa de concreto, o caso da condessa

14 IDRICEANU; BARTLETT. Lendas de sangue. O vampiro na história e no mito, p. 63.

${ }^{15}$ AZEVEDO. O homem, p. 111. 
atravessou os séculos como um dos casos mais aterradores de sadismo e vampirismo. Podemos utilizar o caso verídico de Elizabeth Bathory para reforçar a simbologia do sangue como líquido vital e mantenedor de eterna juventude, como sugere a passagem que segue:

A história da condessa parece incrível, no entanto é derivada de registros de julgamento e de correspondência trocada entre o rei da Hungria e seus oficiais - em outras palavras, de documentos históricos e não de invencionice literária. A não ser que as testemunhas tenham mentido deliberadamente (e não há evidência disso), não há dúvidas de que os fatos descritos realmente aconteceram, ou que de fato se acreditasse neles. Esses extraordinários acontecimentos foram mais tarde registrados pelo reverendo Sabine BaringGould (autor da letra do famoso hino "Avante Soldados de Cristo") em seu livro O Livro dos Lobisomens: Um Relato de Terrível Superstição (1865). Este seria um dos documentos de pesquisa usados por um funcionário público irlandês que se tornou diretor de teatro e autor de um livro chamado Drácula. ${ }^{16}$

Não seria exagero se nós, analisando a personagem Madalena como figura vampírica, a associássemos aos personagens góticos, levando em conta o fato de a moça apresentar, à medida que a narrativa se desenvolve, caracteres típicos de personagens noturnos, ultra-românticos e byronianos, tal qual vemos no texto de Aluísio Azevedo abaixo transcrito:

Foi a partir desse tempo que deu para andar sempre vestida de luto, muito simples, com o cabelo apenas enrodilhado e preso na nuca; um fio de pérolas ao pescoço, sustentando uma cruz de ouro, mais delgada e o seu rosto mais pálido. A tristeza e a concentração davam-Ihe à fisionomia uma severa expressão de orgulho; dir-se-ia que ela, à medida que se humilhava perante Deus, fazia-se cada vez mais altiva e sobranceira para com os homens. O todo era o de uma princesa traída pelo amante, e cuja desventura não conseguira abaixar-Ihe a soberbia, nem arrancar-lhe dos lábios frios uma queixa de amor ou um suspiro de saudade. ${ }^{17}$

Vê-se, portanto, a similitude de Magdá com as figuras aristocráticas do Romantismo da segunda fase: o apreço pelo uso de cores escuras, enlutadas; o cabelo preso em coque, revelando a falta de interesse em adequar-se ao gosto comum; a extrema palidez; e o colar de pérolas, indício de um espírito aristocrático. Há também sua postura de superioridade, seu andar altivo; tudo isso reforça a ideia de uma figura byroniana. $E$ também nos remete à ideia do vampirismo, visto ser o vampiro, tal como concebido na literatura gótica, a partir do século 19, uma figura de hábitos aristocráticos.

Até então, vimos de que forma o romance $O$ homem contém resquícios da mentalidade medieval, tomando como base o aparecimento de fenômenos ligados à possessão sexual e ao vampirismo. A fim de concluirmos o presente trabalho, o que não implica concluir o assunto, por ser este fonte de inesgotáveis pesquisas, trataremos daqui por diante do terceiro aspecto presente na obra que nos remete à residualidade medieval. Trata-se do tema do pecado original.

No romance $O$ homem, os sonhos de Madalena se passam num local paradisíaco, tendo por únicos habitantes ela e o trabalhador Luís, que neste ambiente já não é mais um reles trabalhador rústico e simplório e, sim, um belo e delicado rapaz. Neste éden, como a própria Madalena chama o local, Luís é senhor de tudo, conhece tudo, é sábio e protetor. A natureza que os cerca é abundante e exótica; a semelhança existente entre

${ }^{16}$ IDRICEANU; BARTLETT. Lendas de sangue. O vampiro na história e no mito, p. 143.

17 AZEVEDO. O homem, p. 52. 
este paraíso inventando pela mente da protagonista e o paraíso bíblico é notória; Luís e Magdá também podem ser comparados a Adão e Eva, por serem os únicos habitantes do éden e não terem outra preocupação a não ser amarem-se e viverem harmoniosamente com Deus.

Essa harmonia, contudo, em determinado momento é quebrada pelo aparecimento de um intruso, o Conselheiro, pai de Madalena, que aparece para fragilizar o equilíbrio entre os dois amantes e a natureza. O Conselheiro, que na realidade se configura como homem manso, de modos aristocráticos, bondoso, paciente com os achaques da filha, tolerante e disposto a aceitar qualquer procedimento, contanto que a filha tivesse a saúde restituída, no sonho desta, aparece como um patriarca da Bíblia, repressor, intolerante, conservador, e mais, não só como patriarca hebreu, mas também dotado de caracteres aristocráticos, substituídos por uma postura burguesa e mesquinha. Neste ponto, fica bastante clara uma crítica à hipocrisia burguesa de fins do século 19, mas também há uma ideia que subjaz a essa crítica, a qual seria a ideia dos valores patriarcais judaico-cristãos que fortalecem a figura do homem em detrimento da mulher, colocando esta em situação peremptória de inferioridade. O trecho a seguir põe em cena o aparecimento do Conselheiro e no momento em que surpreende a filha em relação carnal com o cavouqueiro:

Houve um duro silêncio, durante o qual S. Ex.a cujas barbas haviam crescido muito, e cuja calva reluzia que nem a de um patriarca da Bíblia, olhava, ora para a filha, ora para o rapaz, como se estivesse a compará-los.

- Com efeito!...

E sacudia a cabeça, e esticava os beiços, sem desviar a vista. No capricho do sonho, o pobre Conselheiro tinha perdido as suas maneiras distintas e afáveis, e até no modo de se exprimir era grosseiro e burguês.

- Com efeito!... repisou ele, estalando um riso de sarcasmo. - É, até onde pode chegar o aviltamento!... Dar-se a um trabalhador da mais baixa espécie!... É inacreditável! ${ }^{18}$

A ideia de pecado original é reforçada, todavia, quando nos deparamos com um episódio semelhante ao da maçã arrancada da árvore do conhecimento, a ideia de fruto proibido também aparece aqui, porém, transfigurado sob a forma de uma pequenina flor, como se tem no trecho agora transcrito:

Magdá, ao transpor o assombrado átrio da floresta, deteve-se para fazer notar ao companheiro o perfume ativo que se respirava ali; um cheiro como o da magnólia, agudo e penetrante, que ia direito ao cérebro com sutil impressão de frio.

- Vem dessas florinhas que vês aqui nos espiando de todos os lados; essas que ora são cor de rosa, ora avermelhadas, ora cor de laranja e ora cor de sangue. É uma trepadeira; não há canto da ilha em que não a encontres. Mas não toques em nenhuma delas porque se colhesses alguma, nunca mais poderíamos sair daqui.

- Ora essa! Por quê?

- Não sei, é segredo! Foi Deus que assim o quis... Repara: não se descobre uma só dessas flores pelo chão, e também a gente não as vê nascer; quando vão murchando mudam de cor e revivem. ${ }^{19}$

Observamos na passagem transcrita a existência de uma flor que não pode ser colhida, e não há explicação lógica para isso, resumindo-se ao argumento de que apenas Deus

${ }^{18}$ AZEVEDO. O homem, p. 74-75.

${ }^{19}$ AZEVEDO. O homem, p. 109. 
assim o quis e determinou; vemos então a semelhança entre as "florinhas" e a maçã da árvore proibida do Paraíso do Gênesis:

E disse a mulher à serpente: Do fruto das árvores do jardim comeremos, mas do fruto da árvore que está no meio do jardim, disse Deus: Não comereis dele, nem nele tocareis para que não morrais.

Então a serpente disse à mulher: Certamente não morrereis. Porque Deus sabe que no dia em que dele comerdes se abrirão os vossos olhos, e sereis como Deus, sabendo o bem e o mal. ${ }^{20}$

Porém Madalena, tal como Eva, desobedece à lei e arranca a flor proibida, eis a cena apocalíptica que se sucede como conseqüência:

Mal, porém, a flor se desprendeu da haste, um medonho estampido ecoou pelo espaço, deslocando ar e abalando a terra. Magda estremeceu, soltou um grito e viu em menos de um segundo, o rio que cercava a ilha levantar-se com ímpeto e, enovelando-se, arrojar-se para cima das margens opostas e rebentar em pororocas, engolindo a terra. E a montanha, com a sua túnica real, e os monarcas da floresta; com os seus diademas cravejados de predaria, e os prados com as suas cândidas boninas, e os vales com os seus lírios tímidos, tudo defronte dos seus olhos se convertera rapidamente num oceano sem-fim, onde enorme sol vermelho e trôpego se atufava, arquejante, ensangüentando as águas. ${ }^{21}$

É surpreendente, portanto, que Aluísio Azevedo, apesar de cientificista, determinista e defensor da objetividade literária, tenha escrito uma obra marcada pelo maravilhoso e pelo medieval, no que tange à condição feminina de inferioridade representada pela ideia do pecado original. E isto, sabemos estar intimamente ligado ao contexto do século 19, por ser inerente aos valores do Ocidente, mesmo numa época varrida pela onda cientificista. Tais valores podem ser percebidos até se levarmos em consideração paradigmas científicos, ao que nossa personagem Madalena serviria de excelente exemplo pelo fato de seu problema de saúde ser atribuído a "uma perigosa exaltação nervosa que, uma vez agravada, pode interessar-Ihe os órgãos encefálicos e degenerar em histeria", de acordo com as palavras do Dr. Lobão, personagem d'O homem e médico do conselheiro.

A histeria é uma doença muito antiga, julga-se que quem usou esse termo a primeira vez foi o médico grego Hipócrates, referindo-se genericamente a enfermidades do útero. Mas manuscritos egípcios muito mais antigos, anteriores a Hipócrates, já faziam menção a tal doença. Tendo como principais sintomas a paralisia dos membros, ataques com desmaio, acessos dramáticos, esquecimento da língua materna bem como a capacidade de falar idiomas desconhecidos, sufocação, tosse, perda de audição, incapacidade repentina de falar, vômitos e dificuldade em ingerir alimentos, a histeria está associada à figura da mulher, apesar de haver ocorrido também em homens. $O$ auge da histeria ocorreu no século 19, numa sociedade patriarcal, onde a posição da mulher permanecia desfavorecida, e quando as mulheres não podiam exercer sua sexualidade plenamente, pois, de acordo com o pensamento da época, elas não haviam sido feitas para o prazer e, sim, para procriar e cuidar dos afazeres domésticos. Vê-se, portanto, que, ao utilizar a simbologia da fruta proibida e do pecado original trazido ao mundo pela mulher, Aluísio está retomando um arquétipo da mentalidade judaico-cristã, reforçada pela religiosidade medieval, a qual permanece latente na mentalidade ocidental, muitos séculos depois. Chegamos, neste ponto, ao que diz respeito à teoria da residualidade,

${ }^{20}$ ALMEIDA. A Bíblia Sagrada, p. 3.

${ }^{21}$ AZEVEDO. O homem, p. 112. 
visto serem esses aspectos, resíduos, substratos mentais, que permanecem, resistem, mesmo de forma inconsciente nas mentalidades.

O mesmo dá-se com a possessão sexual e o vampirismo discutidos. Ambos, do mesmo modo, remontam à mentalidade medieval, ainda que tenham origem muito mais remota. Contudo, a Idade Média tratou de reforçar essas simbologias, fazendo uso delas no intuito de podar as liberdades individuais e quaisquer manifestações que pudessem fragilizar o poder da Igreja Católica. Observamos, então, no presente trabalho, a presença desses simbolismos, a permanência deles na mentalidade européia, e, conseqüentemente, na brasileira, em forma de resíduos, responsáveis pela configuração de códigos de conduta e moral.

Abstract:

This work intends to show the residual connection between the medieval mentality and the novel $O$ homem, by Aluísio Azevedo, broaching the aspects concerning sexual possession, vampirism, and original sin, which are notable in it. Beyond the referred novel, we use studies by Roberto Pontes about residuality and studies about Middle Ages.

Keywords: Sin; medievalism; residuality

Referências

ALMEIDA, José Ferreira. A Bíblia Sagrada. Traduzida em português. Edição corrigida e revisada. São Paulo: Sociedade Trinitariana do Brasil, 1995.

ASSIS, A. C. M.; MARTINS, E. D. O que se diz e como se pensa a mulher, o sexo e a traição da Idade Média à Literatura de Cordel. In: XXVI ENCONTRO DE INICIAÇÃO À PESQUISA. Fortaleza. CD do XXVI Encontro Universitário de Iniciação à Pesquisa. Fortaleza, 2007.

AZEVEDO, Aluísio. O homem. São Paulo: Martin Claret, 2003.

BOROSSA, Julia. Conceitos da psicanálise: histeria. Trad. Carlos Mendes Rosa. Rio de Janeiro: Relume Dumará; São Paulo: Ediouro, 2005. v. 17.

BURKE, Peter. A Escola dos Annales. (1929-1989): a Revolução Francesa da historiografia. São Paulo: Ed. Unesp, 1997.

DUBY, Georges. A história continua. Trad. Clóvis Marques. Rio de Janeiro: Jorge Zahar, 1993.

IDRICEANU, Flavia; BARTLETT, Waine. Lendas de sangue. O vampiro na história e no mito. Trad. Silvia Spada. São Paulo: Madras, 2007.

LE GOFF, Jacques. Em busca da Idade Média. Com a colaboração de Jean-Maurice de Montremy. Trad. Marcos de Castro. Rio de Janeiro: Civilização Brasileira, 2006. 
LE GOFF, Jacques As raízes medievais da Europa. Trad. Jaime A. Clasen. Petrópolis: Vozes, 2007.

MARTINS, Elizabeth Dias. O caráter afrobrasiluso e residual n'O Auto da Compadecida, de Ariano Suassuna. In: SOARES, Maria Elias; ARAGÃO, Maria do Socorro Silva de (Org.). In: XVII JORNADA DE ESTUDOS LINGUÍSTICOS. Anais... Fortaleza: Universidade Federal do Ceará-UFC/Grupo de Estudos Lingüísticos do Nordeste-GELN, 2000, p. 264-267, v. II.

MONTREMY, Jean-Maurice. Prefácio. In: LE GOFF, Jacques. Em busca da Idade Média. Trad. Marcos de Castro. Rio de Janeiro: Civilização Brasileira, 2006. p. 1113.

PONTES, Roberto. Mentalidade e residualidade na lírica camoniana. In: SILVA, Odalice de C.; LANDIM, T. M. Escritos do cotidiano: estudos de literatura e cultura. Fortaleza: 7 Sóis, 2003. p. 85-102.

PONTES, Roberto. Poesia insubmissa afrobrasilusa. Rio de Janeiro; Fortaleza: Oficina do Autor- EUFC, 1999.

RICHARDS, Jeffrey. Sexo, desvio e danação. As minorias na Idade Média. Trad. Marco Antônio Esteves Rocha e Renato Aguiar. Rio de Janeiro: Jorge Zahar, 1993.

WILLIAMS, Raymond. Marxismo e literatura. Trad. Waltensir Dutra. Rio de Janeiro: Jorge Zahar, 1979. 